\title{
FUNGI IN FORESTRY - SIGNIFICANCE AND RESEARCH IN HUNGARY
}

\author{
ILONA SZABÓ \\ Institute of Forest- and Wood Protection, University of Sopron, Sopron, Hungary
}

The importance of the fungi in forest ecosystems and in forestry as well as a short review of the research of fungi with forestry significance in Hungary are discussed in the paper.

The multiple roles of fungi in forest ecosystems is well known. As heterotrophic organisms their nutrition is pathogenic, symbiotic or saprobic. The mode of nutrition determines their forestry significance. As pathogens they can cause diseases, sometimes death of the forest trees, or discoloration and heart rot in their trunk. As symbiotic partners on roots of forest trees (mycorrhiza) they further the nutrition and defense capacity of trees against the root pathogens. The saprobic activity of fungi decomposing the dead wood and leaf litter is very important in humification process. Fungi are the most important organisms in nature, which have cell wall decomposing capacity. They can cause serious damages by staining and destroying of felled trunks or stored and utilized wood products. The fruit-bodies of many fungi growing in forest are comestible representing not negligible sources of human alimentation.

In the followings the role of fungi as pathogens of forest trees and wood decayers are summarized. A large-scale of fungal systematic groups contains species with abovementioned significance, so this review permits a fairly comprehensive summary of fungal world.

The fungi bearing importance in forestry are shown in actual systematic arrangement [8] (Table I). The review of knowledge and research of these fungi in Hungary was made on the basis of special literature on Hungarian forestry. For reasons of dimensional limit it is possible to cite only a reduced number of selected papers referring mostly to the recent research works. For the same reason the works about the mycorrhiza fungi and non-pathogen pileated fungi which are the subject of other presentations are not cited in this paper.

The research of fungi significant for forestry in Hungary is closely related to the history of Hungarian Academy of Forestry founded in 1808 in Selmeczbánya, the precursor of the University of Sopron. The diseases of forest trees were taught at the 
Table I

System of principal orders of forestry significant fungi from Ainsworth et Bisby's DICTIONARY OF THE FUNGI Eighth Edition (1995)

\begin{tabular}{|c|c|c|}
\hline Kingdom & Phylum & Order \\
\hline Protozoa & Myxomycota & \\
\hline Chromista & Oomycota & Pythiales \\
\hline Fungi & Zygomycota & $\begin{array}{l}\text { Entomophthotales } \\
\text { Mucorales }\end{array}$ \\
\hline \multirow[t]{3}{*}{ Ascomycota } & Diaporthales & $\begin{array}{l}\text { Diatrypales } \\
\text { Dothideales } \\
\text { Eurotiales } \\
\text { Erysiphales } \\
\text { Hypocreales } \\
\text { Leotiales } \\
\text { Microascales } \\
\text { Ophiostomatales } \\
\text { Pezizales } \\
\text { Rhytismatales } \\
\text { Saccharomycetales } \\
\text { Taphrinales } \\
\text { Xylariales }\end{array}$ \\
\hline & Basidiomycota & $\begin{array}{l}\text { Uredinales } \\
\text { Auriculariales } \\
\text { Tremellales } \\
\text { Agaricales } \\
\text { Boletales } \\
\text { Fistulinales } \\
\text { Ganodermatales } \\
\text { Hymenochaetales } \\
\text { Poriales } \\
\text { Schizophyllales } \\
\text { Stereales } \\
\text { Thelephorales }\end{array}$ \\
\hline & Mitosporic fungi & \\
\hline
\end{tabular}

beginning of this academy even if their fungal origin was not known in all cases. The first papers about the fungi pathogenic for forest trees appeared in "Erdészeti Lapok" and "Természettudományi Közlöny", periodicals founded in 1862 and in 1860, respectively, then in "Erdészeti Kísérletek", periodical of the Forestry Research Station founded in 1898. At the turn of the century and in the first decades of the 20th century many articles about a large number of fungi pathogenic for forests were published in the journals mentioned above. The appearance of two epidemic tree diseases in the first half of the 
20th century had an echo in Hungarian special literature of forestry: the powdery mildew of oak caused by Microsphaera alphitoides Grig et Maubl. and the vascular wilt disease of elm caused by Ophiostoma ulmi (Buism.) Nannf. Also the fungi causing heart root of oak were studied in detail at this period of time.

New forest pathological problems appeared and were studies in the second part of our century. The principal objectives were mostly connected to starting of intensive afforestations using hybrid poplars, Scotch and Austrian pine. The forest pathology and wood protection knowledge were synthesized in book form [5, 7].

Recently research themes in forestry mycology are current problems of forest protection as oak decline, death of trees by root diseases, shoot blight of pines etc. The heart rot inducing and wood destroying poroid fungi in Hungary have been systematically investigated [9].

Concerning the mycorrhiza fungi, their importance was known already at the end of the past century. The inoculation of soil with mycorrhiza fungi was a widely applied sylvicultural operation in the 1950s. These fungi are in the focus of current forest mycological researches, too. The importance and composition by species of pileated fungi in forests, as well as the different aspects of their practical utilization (cultivation of comestible fungi, decomposition of different substrata etc.) have been studied.

\section{Systematic treatment}

The slime fungi (Myxomycota) included in kingdom Protozoa have a fairly frequent occurrence in the forests on decaying wood and other organic substrata. Species playing a significant role in diseases of forest trees or in wood protection are not known.

Among the Oomycota classified now in the kingdom Chromista some Phytium and Phytophthora species are known as important root pathogens of different forest trees. In Hungary they were observed in course of mycological investigations related to dampingoff of conifer and beech seedlings, to the ink disease of chestnut and to oak decline.

Fungi belonging to Zygomycota can be found mostly as contaminators of seeds during the storage or germination (Mucorales). Some species of insect-pathogen Entomophthorales were observed on dead insects in sinking stage of gradations.

Ascomycota is the richest in species among the fungal phyla. Genera significant in forestry and some important species are treated shortly in the followings.

To the order Diaporthales belong several leaf-, shoot- and bark disease causing species. Some are weak or mild pathogens having a role in decline processes of different tree species, others are aggressive pathogens. Apiognomonia and Gnomonia species cause leaf and shoot necrosis of trees mostly of anthracnose type [20]. Valsa species living in the bark of forest trees are weak pathogens, contributing to death of branches of weakening trees. They were studied especially in the case of poplars [12]. Diaporthe species are also weak pathogens in the bark of different trees. Bark necrosis caused by them was observed on young oaks (D. leiphaemia /Fr./Sacc.) and robinia (D. oncostoma /Duby/Fuck). Cryptodiaporthe populea (Sacc.)Butin is the agent of bark chancre of poplars. Its biology and the conditions of disease were studied in detail by forest pathologists in Hungary [3, 12]. Cryphonectria parasitica (Murrill)Barr, a very aggressive pathogen, causes bark cancer of chestnut. Found first time in 1969, now it is present in all the chestnut stands and plantations causing great ravages. The natural hypovirulent strains 
of the fungus are found in Hungary, their application in biological suppression of the disease is tested [16].

The order Diatrypales includes in the bark living saprobic or weak pathogen fungi. Some species are very common on dead branches in forests. They can cause saprobic wood stain of fresh felled trunks of broad-leaved trees, followed by an incipient decay.

Dothideales contain many species occurring on forest trees. Cucurbitaria and Botryosphaeria species are weak pathogens living in bark. Some Botryosphaeria species were found during the mycological investigations related to oak decline, the pathogeny of B. stevensii Shoemaker on young oaks was demonstrated [23-25]. According to recent observations this species is implicated in stock cancer syndrome of turkey oak. Scirrhia pini Funk et Parker which recently has appeared in Hungary is a dangerous needle pathogen of pines, especially of Austrian pine [19]. The Mycosphaerella species are leaf and needle pathogens on different trees. Venturia species are important leaf and shoot pathogens on poplars and willows [12].

Endomycetales, the yeast fungi, occur in the forests primarily in slime-flux of the trees of different origin.

The species of Eurotiales are known mostly in their anamorph state Penicillium and Aspergillus. They contaminate the seeds during the storage affecting their germination capacity and cause a superficial discoloration, mould of wood products stored in wet condition.

Among the Erysiphales the powdery mildew of oaks (Microsphaera alphitoides Griff. et Maubl.) is very common, dangerous especially in nurseries and young plantations of pedunculate oak. It was found in Hungary for the first time in 1908, its perithecia were detected in 1922 only. The powdery mildews of other forest trees (Uncinula spp. on maples, poplars and willows, Phyllactinia guttata (Wallr. ex Fr.)Lev. on several tree species etc.) are less important, their symptoms appearing mostly at the end of the growing season.

Some Nectria species belonging to the order Hypocreales are bark pathogens causing cancer of various trees ( $N$. ditissima Tul. on beech, $N$. galligena Bres. on poplars, ash and other trees). Other Nectria species are contributing factors to decline diseases as weak pathogens ( $N$. coccinea /Pers./Fr. on beech, $N$. cinnabarina /Tode/Fr. on several woody plants). The Nectria species important for the forestry were studied in Hungary already in the first years of the 20th century. $N$. radicicola Gerlach et Nilson, a root pathogen of different young trees in nurseries and natural renewals, was recently found in Hungary.

The order Leotiales contains several pathogens. Drepanopeziza species cause leaf spots of poplars and willows. They were investigated especially on poplars in connection with breeding programs [4]. Lachnellula willkommii (Hartig)Dennis causes cancer disease of larch known in Hungary already in the late 19th century. Cenangium ferruginosum Fr. is a pathogen of pines causing shoot and twig death. It was identified in relation with the deaths of Austrian pine during the earlier epidemics as well as at the present time [17]. Botryotinia fuckeliana (de Bary)Whetz. in its anamorphe state (Botrytis cinerea Pers.) is a pathogen causing the death of the young shoots of conifers. The disease was studied and described for the first time in Hungary in 1900. Ciboria batschiana (Zopf)Buchw. damages oak acorns causing their mummification. 
From the order Microascales the Ceratocystis species has importance. $C$. fagacearum (Bretz)Hunt causing vascular wilt of oaks in North America does not occur in Europe. Some other species are endophyte or decline pathogens in various trees, as $C$. erinaceus described recently in Hungary $[1,2]$.

Ophiostoma ulmi (Buism.)Nannf. (Ophiostomatales) is the agent of elm vascular wilt. Its epidemic started in Europe at the late 1910s. The disease was found in Hungary in the 1930s. The more aggressive strain of the fungus was reintroduced in Europe from America in the 1960 s, causing the present epidemic. It is considered as a distinct species now, named $O$. novo-ulmi Brasier. Other Ophiostoma species especially $O$. piceae (Münch)H. Sydow et Sydow are known as contributing factors in decline diseases of oak and beech $[1,23]$. Some species cause the blue stain of conifer wood after felling or death of the trees [5].

The order Pezizales contains mostly saprobic fungi growing on soil or decaying wood. Rhizina undulata is a pathogen Fr. which can attack the roots of conifers under special conditions [18].

Rhytisma acerinum (Pers.)Fr. (Rhytismatales) is common in Hungary causing tar spot disease of maples. Lophodermium seditiosum Minter, Staley et Millar is one of the most important needle pathogens of pines in nurseries. Its biology as well as the methods of defence against it were studied in detail [13].

Taphrina species (Taphrinales) induces hypertrophic symptoms as leaf blister witch's broom or fruit deformation of some broad-leaved forest trees.

Xylariales contains mostly saprobic species common on dead wood. Some of them can affect the wood quality of felled trunks causing saprobic wood stain. Ustulina deusta (Hoffm.)Petrak causes discoloration of wood in living trees. Rosellinia quercina Hartig is a root pathogen of young oaks.

Phylum Basidiomycota contains a great number of fungi important in the forestry: pathogens, mycorrhiza partners, decomposers etc.

In Hungary about 100 rust fungus species (Uredinales) have been registered on various forest trees and shrubs. Only a few of them have practical importance for forestry. Melampsora species causing leaf rust of poplars were studied in the 1960s and 1970s in relation with breeding of these trees. The investigation of different biotypes of these rust fungi has been started recently in our country [22]. Cronartium ribicola J.C.Fisher, the agent of blister rust of white pine causes serious damages in young plantations of this tree species.

The orders Auriculariales, Dacrymycetales, Tremellales contain saprobic species occurring on dead, decaying wood, they play some role in decomposition processes in the forests.

Agaricales and Boletales include the most part of fungi important as litter decomposers, mycorrhiza partners or edible fungi. The significance of these fungi in the forestry ecosystems as well as their composition by species has been researched by several mycologists.

Armillaria species (Agaricales) have importance as root pathogens of forest trees. They represent an important factor in decline processes of forest trees [23]. The identification of species and their hosts in Hungary is going on [21]. Pholiota species can attack living trees through the stem wounds, for example Ph. destruens (Bond.)Quel., a 
frequent wound pathogen and wood stain agent in living poplars. It causes a rapid white decay of wood after felling [12].

To the Boletales belong the most dangerous decayers of wood in buildings: Serpula lacrimans (Wulf. In Jack.ex Fr.)Schroeter and Coniophora puteana (Schum.ex Fr.)P.Karst. They were studied by many specialists primarily regarding defence possibilities [5].

The further orders contain the most important heart rotters of living trees and decayers of wood products. They can cause major losses of wood production. These species have been studied recently in Hungary [9]. Some frequent species are as follows:

Fistulina hepatica (Schaeff.)Fr. (Fistulinales) causes butt rot of aged oaks. It is a brown rotter (It decomposes holocellulose, but not lignin).

Ganoderma adspersum (Schulz.)Donk (Ganodermatales) is a white butt rotter of many tree species (It decomposes holocellulose as well as lignin).

Inonotus nidus-pici Pilat (Hymenochaetales) is a white heart rotter, very frequent on turkey oak (Quercus cerris L.), causing severe losses.

Frequent species from the order Poriales: Polyporus squamosus (Huds.)ex Fr. (white rot), Laetiporus sulphureus (Bull.ex Fr.)Murrill (brown rot) occur on more tree species. They are wound pathogens causing heart rot of their hosts. Heterobasidion annosum (Fr.)Bref. can be considered as one of the most dangerous pathogens in planted pine stands. It attacks the roots thus causing death of the trees. The biology of this species, the possibilities of protection against it and recently its population structure have been objects of detailed studies [14, 15]. Pleurotus ostreatus (Jack.)Quel., wound pathogen, causes stain in living trees and white decay after felling. This fungus was studied concerning its utilization for decaying of the stumps before reforestation of the terrain [10]. It is one of the most favourite cultivated fungus. Its breeding and gene bank completing are under study.

Schizophyllum commune (Fr.)Fr. (Schizophyllales) occurs frequently on branches of declining or dead trees.

Stereum species (Stereales) are mostly saprobic decayers frequent on dead wood in the forests. Phlebiopsis gigantea (Fr.)Jülich is utilized in biological prevention of infection with Heterobasidion annosum in Pinus stands [14].

Mostly saprobic fungi belong to the order Thelephorales. Thelephora terrestris Fr. is known to overgrow the conifer seedlings but it can be a mycorrhiza partner at the same time.

The group of Mitosporic fungi is not accepted as a systematic category in the actual fungal system. Only some of the important species are mentioned here:

Sphaeropsis sapinea (Fr.)Dyko et Sutton is the agent of the disease known as sphaeropsis blight of pines. It is very frequent and causes serious damages in Austrian pine stands. Its biology under Hungarian conditions has been cleared recently [11]. The leaf disease causing Coelomycetes have been studied concerning the occurrence of species and their hosts [20]. Some Fusarium species cause damping-off of conifer seedlings [6]. Bark cancers or vascular discoloration of Fusarium origin have been observed on poplars and robinia, respectively on oak. Conidial fungi include some antagonist species (Trichoderma, Ampelomyces) employable against the pathogen fungi of forest trees. Rhizoctonia solani Kiihn. is a frequent root pathogen on the seedlings. 


\section{REFERENCES}

1. Bohár,Gy:: Ecological and pathological role of Ophiostoma and Ceratocystis species in diseases of woody plants. (in Hungarian) Proceedings of the Changing Health Condition of Forests Conference organised by the Forestry Committee of the Hungarian Academy of Sciences Budapest 23 1995. pp. 3150-157.

2. Bohár,Gy: Ceratocystis erinaceus: a new endophyte in the heartwood of oak. Acta Phytopathologica et Entomologica Hungarica 31(3-4), 213-218 (1996)

3. Folcz,T.: Home life-cycle and damage of the poplar bark decay causing fungus Dothichiza populea. (in Hungarian) Dissertation. Erdészeti és Faipari Egyetem Sopron, 1993.

4. Gergácz,J.: Marssonina damage on poplars. (in Hungarian) Az Erdô 16, 304-308 (1967).

5. Gyarmati,B., Igmándy,Z., Pagony,H.: Faanyagvédelem. (Wood protection) Mezôgazdasági Kiadó, Budapest. 1964. p. 346.

6. Hangyál,W:: Fusarium-Arten als Erreger der Umfallkrankheit an Sämlingen der gemeinen Kiefer und Schwarzkiefer. (in Hungarian) Erdészeti Kísérletek 67, 167-180 (1971).

7. Haracsi,L.: Erdészeti növénykórtan. (Forest pathology) Akadémiai Kiadó, Budapest. 1969. p. 316.

8. Hawksworth,D.L., Kirk,P.M., Sutton,B.C., Pegler,D.N.: Ainsworth Bisbi's Dictionary of the Fungi. Eighth Edition prepared by the International Mycological Institute CAB International 1995. p. 616.

9. Igmándy,Z: A magyar erdôk taplógombái. (Tinder fungi of the Hungarian forests) Akadémiai Kiadó, Budapest. 1991. p. 113.

10. Kiss,L., Pagony,H.: Importance and economic efficiency of artificial stump decomposition. (in Hungarian) Erdészeti Kutatások 72, 115-121 (1976).

11. Koltay,A.: Recent results on biology of pathogen Sphaeropsis sapinea Dyko et Sutton causing Austrian pine shoot blight. (in Hungarian) Erdészeti Kutatások 88, 250-271 (1998).

12. Pagony,H.: Diseases of poplars caused by fungi in Hungary. (in Hungarian) Erdészeti Kutatások 68(2), 9399 (1972).

13. Pagony,H.: Results in connection with the research of pine needle cast fungus /Lophodermium pinastri (Schrad.)Schev./ (in Hungarian) Növényvédelem 12, 349-353 (1976).

14. Pagony,H.: Application possibility of the fungus Peniophora gigantea/Fr./Masse to combat the root decaying fungus /Fomes annosus (Fr.)Cooke/ in our Scotch and Austrian pine stands. (in Hungarian) Erdészeti Kutatások 76-77, 279-286 (1984-1985).

15. Pagony,H., Szántó,M.: Biotypes of root decaying fungus /Heterobasidion annosum (Fr.)Bref./ in Hungary. (in Hungarian) Növényvédelem 33, 11-17 (1997)

16. Radócz,L., Szabó,I., Varga,M.: Biological control of chestnut blight /Cryphonectria parasitica (Murr.)Barr/ in Hungary. (in Hungarian) Növényvédelem 33, 3-10 (1997).

17. Szabó,I: Mycological studies in connection with the shoot blight of Austrian pine /Pinus nigra Arn./. (in Hungarian) Növényvédelem 27, 438-443 (1991).

18. Szabó,I:: Pathogenicity of the fungus Rhizina undulata on Austrian pine seedlings. (in Hungarian) Növényvédelem 28, 117-119 (1992).

19. Szabó,I:: Appearance of Dothistroma septospora (Dorog.)Morelet in Austrian pine plantations. (in Hungarian) Erdészeti Lapok 132, 44 (1997).

20. Szabó,I.: Some foliage necrosis causing Coelomycetes on broad leaves forest trees and shrubs in the surrounding of Sopron, Hungary. Acta Phytopathologica et Entomologica Hungarica 32(1-2) 69-78 (1997).

21. Szántó,M.: Occurrence and host plants of Armillaria mellea Fr. in Hungary. (in Hungarian) Erdészeti Kutatások 84, 177-182 (1994). 
22. Szántó,M., Steenackers,M.: Preliminary data from the occurrence of Melampsora species on poplar in Hungary. (in Hungarian) Erdészeti Kutatások 88, 119-130 (1998)

23. Vajna,L.: Fungi species playing role in decay of sessile oak. (in Hungarian) Erdészeti Kutatások 79, 233235 (1987).

24. Vajna,L.: Branch canker and dieback of sessile oak (Quercus petraea) in Hungary caused by Diplodia mutila. European Journal of Forest Pathology 16, 223-229 (1986).

25. Vajna,L: Pathogenic Botryosphaeria species in Hungary. I. Botryosphaeria stevensii Schoemaker (in Hungarian) Növényvédelem 33, 549-556 (1997). 